УДК 579.67

\title{
МЕТОДЫ ОПРЕДЕЛЕНИЯ МИКРОБНОГО ЗАГРЯЗНЕНИЯ КИСЛОМОЛОЧНОГО СЫРА
}

\author{
Исламова Хава Султановна \\ биолого-химический факультет \\ Научный руководитель: Дохтукаева Айна Магомедовна \\ к.б.н., доцент \\ ФГБОУ ВО «Чеченский государственный университет»
}

Аннотация. Обеспечение населения качественными кисломолочными продуктами является важнейшей задачей современного рынка, ведь, в первую очередь, их главными потребителями являются дети. Поэтому, санитарномикробиологический контроль качества кисломолочных продуктов, в данном случае зернистого творога, должен осуществляться на высоком уровне, особенно это касается рыночной продукции.

Ключевые слова: кисломолочный продукт, микрофлора, творог, методы, стрептококки.

\section{METHODS FOR DETERMINING MICROBIAL CONTAMINATION OF FERMENTED MILK CHEESE}

\section{Islamova Hava Sultanovna}

2nd year master's student of the Faculty of biology and chemistry Research Supervisor: Aina Magomedovna Dokhtukayeva candidate of Biological Sciences, Associate Professor

Chechen State University

\begin{abstract}
Providing the population with high-quality fermented milk products is one of the important tasks of the modern market, because, first of all, their main consumers are children. Therefore, sanitary and microbiological quality control of fermented milk products, in this case, granular cottage cheese, should be carried out at a high level, especially for market products.

Key words: fermented milk product, microflora, cottage cheese, methods, streptococci.
\end{abstract}


Кисломолочные продукты занимают особое место в пищевом рационе человека и пользуются большим потребительским спросом благодаря своим вкусовым качествам и диетическим свойствам. Они содержат все необходимые вещества, которые обеспечивают нормальную жизнедеятельность человека, легко усваиваются, способствуют легкому процессу переваривания пищи, регулируют и, при необходимости, восстанавливают микробиоценоз кишечника [1, с. 79].

Вместе с тем, кисломолочные продукты являются прекрасной средой для развития условно-патогенной и патогенной микрофлоры, которая, во-первых, может стать причиной их порчи, а, во-вторых, привести к пищевым интоксикациям и токсикоинфекциям. Под действием бактерий, дрожжей и плесневых грибов при несоблюдении санитарных норм приготовления этих продуктов, перевозки, хранения и реализации молочные продукты быстро портятся, теряют свою пищевую ценность, становятся небезопасными для употребления [6, с.58].

Зернистый кисломолочный сыр (зернистый творог) - разновидность кисломолочного, который имеет большие размеры белковых гранул, не связанных между собою. Данный продукт занимает промежуточное положение между кисломолочным и твердым сыром и отличается от них по внешнему виду и вкусу: крупные белковые гранулы с нежным кисловатым вкусом, залитые слегка подсоленными сливками. Особенностью микробиологических процессов, которые происходят при производстве зернистого кисломолочного творога, является подогревание сырного зерна до 55-60 ${ }^{\circ} \mathrm{C}$ и его промывание водой [8, с.216].

В состав заквасок для получения кисломолочного сыра входят молочнокислые стрептококки - лактококки и лейконостоки. Все лактококки являются грампозитивными факультативными анаэробами, споронеобразующие, капсулы, как и все кокки, не имеют. Многим лактококкам свойственно проявлять протеолитическую активность. Бактерии Lactococcus lactis и Lactococcus cremoris относятся к группе гомоферментативным лактококкам. L.lactis является первым микроорганизмом, который был выделен в чистой культуре листером в 1873 г. Также для данного вида молочнокислых бактерий свойственно образовывать антибиотик низин. Морфология клеток молочнокислого лактококка разнообразна: в молодых культурах имеет вид коротких цепочек из 2, 3,4 или 5 клеток, в старых культурах расположение попарное, иногда клетки имеют овальную форму.

Культуральные свойства молочнокислых бактерий специфичны. При росте на твердых средах на поверхности этих сред образуют росинчатые округлые 
колонии с ровными краями, а чечевицеподобные колонии врастают в агар. На основных средах рост не дают, предпочитая сложные среды с добавками молочной сыворотки или гидролизованного молока. Оптимальная температура роста составляет $30-35^{\circ} \mathrm{C}$.

L. lactis является активным кислотообразователем, молоко сквашивает в течение 6-10 ч, с кислотностью $120^{\circ} \mathrm{T}$. Сквашенное молоко имеет ровный плотный сгусток и приятный кислый вкус и запах. Некоторые штаммы образуют сгусток вязкой, тягучей консистенции, поэтому непригодны для производства кисломолочных продуктов [7, с.17].

Количество микроорганизмов в готовом продукте зависит от температуры хранения. Так, при низких температурах хранения зернистого творога угнетается рост молочнокислых бактерий, но создаются условия для развития психрофильных микроорганизмов, которые попадают в готовый продукт после промывания зерна. При повышенных температурах хранения зернистого кисломолочного сыра увеличивается количество мезофильных лактококков, что приводит к скисанию сливок и образованию сметаны [5, с.80].

Методы определения молочнокислых бактерий основаны на высеве определенного количества продукта и (или) его разведений в жидкие или на плотные селективные питательные среды, культивировании посевов при оптимальных условиях и, при необходимости, определении морфологических и биохимических свойств обнаруженных микроорганизмов и их подсчете [2].

Приготовление разведений кисломолочных продуктов осуществляется по ГОСТ 9225-84 [3]. Высев для подсчета количества молочнокислых бактерий проводится в агаризованую или жидкую питательную среду (табл 1).

Таблица 1

\section{Характер роста молочнокислых бактерий на агаризованых и в жидких питательных средах}

\begin{tabular}{|c|c|c|}
\hline Микроорганизмы & Питательная среда & $\begin{array}{c}\text { Характеристика колоний } \\
\text { или характер роста в жидкой среде }\end{array}$ \\
\hline \multirow{3}{*}{$\begin{array}{l}\text { Молочнокислые } \\
\text { бактерии }\end{array}$} & Бликфельдта жидкая & $\begin{array}{l}\text { Изменение цвета среды от } \\
\text { фиолетового к желтому, помутнение } \\
\text { среды или образование осадка, } \\
\text { возможно выделение газа. }\end{array}$ \\
\hline & $\begin{array}{l}\text { Бликфельдта агаризованная, } \\
\text { среда из томатного сока }\end{array}$ & $\begin{array}{l}\text { Колонии мелкие гладкие или } \\
\text { шершавые }\end{array}$ \\
\hline & Капустный агар & Колонии окружены прозрачной зоной. \\
\hline
\end{tabular}




\begin{tabular}{|c|c|c|}
\hline Микроорганизмы & Питательная среда & $\begin{array}{c}\text { Характеристика колоний } \\
\text { или характер роста в жидкой среде }\end{array}$ \\
\hline $\begin{array}{l}\text { Молочнокислые } \\
\text { бактерии рода } \\
\text { Leuconostoc }\end{array}$ & $\begin{array}{l}\text { Агар питательный с } \\
\text { сахарозой }\end{array}$ & $\begin{array}{l}\text { Колонии выпуклые, округлые, } \\
\text { слизистые. При удалении колоний } \\
\text { иглой или бактериологической петлей } \\
\text { тянутся волокна слизи. }\end{array}$ \\
\hline $\begin{array}{l}\text { Молочнокислые } \\
\text { бактерии рода } \\
\text { Streptococcus }\end{array}$ & Редди & $\begin{array}{l}\text { S. lactis образует белые колонии, } \\
\text { маленькие, круглые, вокруг колоний } \\
\text { могут быть зоны просветления } \\
\text { S.cremoris колонии мелкие, желтые, } \\
\text { элипсовидные. }\end{array}$ \\
\hline $\begin{array}{l}\text { Молочнокислые } \\
\text { бактерии рода } \\
\text { Lactococcus }\end{array}$ & Среда Бригс & $\begin{array}{l}\text { Колонии мелкие, гладкие или } \\
\text { шершавые }\end{array}$ \\
\hline $\begin{array}{l}\text { Молочнокислые } \\
\text { стрептококки } \\
\text { S.thermophilus }\end{array}$ & Среда Lee & $\begin{array}{l}\text { Колонии желтые круглые или } \\
\text { элипсовидные, вокруг которых } \\
\text { наблюдаются зоны просветления }\end{array}$ \\
\hline
\end{tabular}

По числовой характеристике по табл. 2 необходимо найти наиболее достоверное число молочнокислых микроорганизмов и умножить его на то разведение, с которого начиналась первая цифра числовой характеристики.

Таблица 2

\section{Числовая характеристика молочнокислых микроорганизмов}

\begin{tabular}{|l|l|l|l|}
\hline $\begin{array}{c}\text { Числовая } \\
\text { характеристика }\end{array}$ & $\begin{array}{c}\text { Наиболее достоверное } \\
\text { число микроорганизмов } \\
\text { при заражении двух } \\
\text { параллельных пробирок }\end{array}$ & $\begin{array}{c}\text { Нисловая } \\
\text { характеристика }\end{array}$ & $\begin{array}{c}\text { Наиолее достоверное } \\
\text { чио микроорганизмов } \\
\text { при заражении двух } \\
\text { параллельных пробирок }\end{array}$ \\
\hline 001 & 0,5 & 200 & 2,5 \\
\hline 010 & 0,5 & 201 & 5,0 \\
\hline 011 & 0,9 & 210 & 6,0 \\
\hline 020 & 0,9 & 211 & 13,0 \\
\hline 101 & 1,2 & 212 & 20,0 \\
\hline 110 & 1,3 & 220 & 25,0 \\
\hline 120 & 2,0 & 221 & 70,0 \\
\hline 121 & 3,0 & 222 & 110,0 \\
\hline
\end{tabular}


Полученное число должно отвечать количеству клеток молочнокислых бактерий в 1 г продукта [3].

Для определения дрожжей и плесневых грибов из подготовленной пробы продукта и (или) его разведения необходимо отобрать навеску объемом $1 \pm 0,1 \mathrm{~cm}^{3}$.

Продукт и (или) его разведение высеваются согласно ГОСТ 9225-84 параллельно в две чашки Петри. Посевы заливают расплавленным и охлажденным до температуры $45 \pm 1{ }^{\circ} \mathrm{C}$ средой и термостатируют при температуре $24 \pm 1^{0} \mathrm{C}$ в течение 5 суток. Через 3 суток термостатирования проводится предварительный учет типичных колоний или фиксируется появление характерных признаков роста в жидких питательных средах [3].

Если в посевах на агаризованных средах присутствуют мукоровые (грибы, которые очень быстро растут), то учет предварительных результатов необходимо проводить очень осторожно, не допуская того, чтобы споры этих грибов высыпались и дали рост вторичных колоний. Через 5 суток проводится окончательный учет результатов после термостатирования посевов. Колонии дрожжей и плесневых грибов различаются визуально.

Рост дрожжей на агаризованных средах сопровождается образованием больших, выпуклых, блестящих, серо-белых колоний с гладкой поверхностью и ровным краем. Развитие дрожжей в жидкой питательной среде сопровождается появлением помутнения, запаха брожения и газа. Развитие плесневых грибов на питательных средах сопровождается появлением мицелия различной пигментации.

Для количественного подсчета необходимо отобрать чашки, на которых выросло от 15 до 150 колоний дрожжей и (или) от 5 до 50 колоний плесневых грибов.

Для разделения колоний дрожжей и плесневых грибов проводят микроскопические исследования. Для этого из отдельных колоний или из посевов в жидкую среду готовятся препараты методом раздавленной капли.

Результаты микроскопирования оценивают, пользуясь характеристикой дрожжей и плесневых грибов, отмеченной в табл. 3., причем, по каждой пробе отдельно. 
Таблица 3

Характеристика дрожжей и плесневых грибов

\begin{tabular}{|l|l|}
\hline $\begin{array}{c}\text { Группа } \\
\text { микроорганизмов }\end{array}$ & \multicolumn{1}{c|}{ Характеристика } \\
\hline \multirow{2}{*}{ Дрожжи } & $\begin{array}{l}\text { Одноклеточные микроорганизмы, клетки круглой, овальной } \\
\text { или продолговатой формы, длиной от } 2,5 \text { к 30мкм и шириной } \\
\text { от 2,5 до } 10 \text { мкм, часто почкуются }\end{array}$ \\
\hline Плесневые грибы & $\begin{array}{l}\text { Состоят из нитей-гиф, без перегородок или септированных на } \\
\text { клетки. Гифы образует боковые выросты и разветвления, от } \\
\text { вегетативных гиф отходит гифа, которая несет плодовые тела }\end{array}$ \\
\hline
\end{tabular}

\section{Список литературы}

1. Бредихин С. А. Технология и техника переработки молока / С. А. Бредихин, Ю. В. Космодемьянский, В. Н. Юрин. - М: Колос, 2003. C.259-324.

2. ГОСТ 10444.11-88, Продукты пищевые. Методы определения молочнокислых микроорганизмов. - М: ИПК Издательство стандартов, 2002. $15 \mathrm{c}$.

3. ГОСТ 9225-84, Молоко и молочные продукты. Методы микробиологического анализа. - М: ИПК Издательство стандартов, 1997. - 16с.

4. Гудков А. В. Сыроделие: технологические, биологические и физикохимические аспекты /под ред. А. В. Гудкова. М.: Делипринт, 2003. C. $408-425$ (800c.).

5. Жариков Г. Г. Основы микробиологии / Г. Г. Жариков, И. Б. Леонова. М: Академия, 2008. - 144 с.

6. Красникова Л. В. Микробиология молока и молочных продуктов / Л. В. Красникова, П. И. Гунькова. - Санкт Петербург: ГУНиПТ, 2006. - 63 с.

7. Кудрявцева Т. А. Получение и применение бактериальных заквасок для производства кисломолочных продуктов, масла и сыров / Т. А. Кудрявцева. Санкт Петербург: ГАХПТ, 1998. - С.16-19.

8. Мудрецова-Висс К. А. Микробиология санитария и гигиена / К. А. Мудрецова-Висс. - М: Форум, 2008. - 400 с. 